\title{
PENGEMBANGAN INVESTASI MELALUI PENDIRIAN UNIT SYARIAH
}

\author{
Sulistianingsih Rahayu \\ Magister Ilmu Hukum Fakultas Hukum, Universitas Mataram \\ Lombok, NTB, Indonesia \\ Email : Sulisrahayu0917@gmail.com
}

\begin{abstract}
Abstrak
LahirnyaUndang-Undang Nomor 1 Tahun2016tentang Penjaminanyangberlaku efektifpada 2019 telah membuka peluang pasar yang lebih besar kepada industri penjaminan, termasuk perusahaan penjaminan syariah. Untuk itu PT. Jamkrida NTB Bersaing awalnya bergerak dalam bidang penjaminan konvensional dalam perkembangannya akan mengembangkan investasinya melalui pendirian unit syariah. Akan tetapi hingga saat ini masih terbentur oleh kecukupan modal yang dipersyaratkan oleh peraturan perundang-undangan. Sebab hingga saat ini PT. Jamkrida NTB belum memenuhi standar minimal permodalan yang disyaratkan oleh Peraturan Otoritas Jasa Keuangan. Penelitian ini merupakan penelitian hukum normative dengan menggunakan pendekatan perundang-undangan, konseptual dan kasus. Hasil penelitian menunjukkan bahwa pendirian lembaga penjaminan kredit secara yuridis normative diatur dalam Undang-Undang Republik Indonesia Nomor 1 tahun 2016 tentang Penjaminan, Peraturan Menteri Keuangan Nomor 222/PMK.010/2008 tentang Perusahaan Penjaminan Kredit dan Perusahaan Penjaminan Ulang Kredit dan Peraturan Otoritas Jasa Keuangan Nomor 2/POJK 05/2017 tentang Penyelenggara Usaha Lembaga Penjamin. Kedua bahwa berdasarkan ketentuan Pasal 11 Peraturan Menteri Keuangan Nomor 222/ PMK.010/2008 tentang Perusahaan Penjaminan Kredit dan Perusahaan Penjaminan Ulang Kredit: Jumlah modal disetor atau simpanan pokok, simpanan wajib dan hibah penjamin ditetapka paling sedikit Rp. 100.000.000.000 (seratus miliar untuk lingkup nasional dan Rp. 50.000.000.000 (lima puluh miliar) untuk lingkup propinsi. Kemudian untuk Penjamin dan Penjamin Ulang yang membuka Unit Usaha Syariah wajib menyediakan dana awal paling sedikit sebesar Rp10.000.000.000,00 (sepuluh miliar rupiah) serta membuka Kantor Cabang Syariah yang baru atau mengubah kegiatan usaha Kantor Cabang yang melakukan kegiatan usaha secara konvensional menjadi Kantor Cabang Syariah.
\end{abstract}

Kata kunci: Lembaga Penjaminan Kredit; Unit Syariah; Investasi.

\section{Abstract}

The issuance of Law No. 1 of 2016 concerning Guarantees which became effective in 2019 has opened up greater market opportunities for the guarantee industry, including sharia guarantee companies. For this reason, PT. Jamkrida NTB Bersaing initially engaged in the conventional guarantee sector in its development will develop its investment through the establishment of sharia units. However, until now it is still hampered by the capital adequacy required by legislation. Because until now PT. Jamkrida NTB has not met the minimum capital standards required by the Financial Services Authority Regulation. This research is a normative legal research using a statutory, conceptual and case approach. The results showed that the establishment of a normative credit guarantee institution was regulated in Law of the Republic of Indonesia Number 1 of 2016 concerning Guarantees, Regulation of the Minister of Finance Number 222 / PMK.010 / 2008 concerning Credit Guarantee Companies and Credit Guarantee Companies and Financial Services Authority Regulations Number 2 / POJK 05/2017 concerning Business Organizers of Guarantor Institutions. Secondly, based on the provisions of Article 11 of the Minister of Finance Regulation No. 222 / PMK.010 / 2008 concerning Credit Guarantee Companies and Credit Reinsurance Companies: The amount of paid up capital or principal savings, mandatory savings and guarantor grants is at least Rp. 100,000,000,000 (one hundred billion for the national scope and Rp. 50,000,000,000 (fifty billion) for the provincial scope. Then for the 
Guarantor and Guarantor who opens the Sharia Business Unit is required to provide an initial fund of at least Rp 10,000,000,000.00 (ten billion rupiah) and open a new Sharia Branch Office or change the business activities of a Branch Office that conducts conventional business activities to Sharia Branch Offices.

\section{Keywords: Credit Guarantee Institution; Sharia Unit; Investation.}

\section{A. PENDAHULUAN}

Setiap manusia membutuhkan rasa aman dari kemungkinan bahaya yang menimpa diri dan harta benda miliknya. Peningkatan teknologi dan pembangunan umumnya, selalu disertai dengan semakin tinggi risiko yang mengancam dalam kehidupan dan mengakibatkan kerugian bagi manusia.

Manusia selalu berupaya untuk menghadapi risiko tersebut, antara lain dengan; Menghindari (avoidance) sebagai upaya dari seseorang untuk melakukan sesuatu perbuatan atau tidak melakukan sesuatu perbuatan, dengan tujuan agar peristiwa yang tidak pasti tidak terjadi, sehingga tidak menimbulkan kerugian; Mencegah (prevention), yaitu dalam hal seseorang melakukan tindakan tertentu dengan tujuan agar suatu peristiwa yang tidak pasti tidak terjadi, dan kalaupun peristiwa tidak pasti tersebut terjadi, paling tidak kerugian yang ditimbulkannya dapat dikurangi; Mengalihkan (transfer), dalam keadaan seseorang berupaya mengalihkan kerugian yang ditimbulkan dari suatu peristiwa yang tidak pasti, kepada pihak lain yang bersedia menerima peralihan kerugian tersebut; Menerima (asumpation of retention) yang merupakan sikap pasrah dari seseorang atau tidak melakukan tindakan apapun, untuk mengatasi kemungkinan kerugian yang akan diderita, akibat dari terjadi peristiwa tidak pasti yang menimpa diri maupun harta benda miliknya. ${ }^{1}$

Praktek sejenis asuransi sudah dikenal sejak 4000 Tahun sebelum Masehi, yang dilakukan oleh pedagang di lembah sungai Tigris (wilayah Irak) yang membutuhkan proteksi atas ketidakpastian yang dirasakan dalam keselamatan kegiatan mereka, yang didukung oleh berbagai faktor yang menimbulkan rasa tidak aman. Pengaturan atas praktek tersebut baru ada atau baru diketahui ada 2100 Tahun sebelum Masehi dalam code Hammurabi pada zaman kerajaan Babilonia. Pengaturan didasarkan pada asas "semua untuk satu", selanjutnya pengaturan asuransi dengan sistem premi tetap, mulai dipergunakan pada zaman Iskandar Zulkarnain. ${ }^{2}$

Konsep asuransi Islam sudah dikenal sejak zaman Rasulullah yang dikenal dengan aqilah. Mekanisme sejenis asuransi syariah (aqilah) sudah sering dilakukan masyarakat Arab Kuno. Aqilah bermakna asabah yang menunjuk hubungan kekerabatan dari pihak orang tua laki-laki pembunuh. Pemikiran dasar tentang aqilah adalah mempersiapkan pembayaran sebagai uang iuran (kontribusi) untuk kepentingan si pembunuh sebagai pengganti kerugian untuk ahli waris korban, sama dengan premi pada praktek asuransi, sementara kompensasi pembayaran dengan aqilah dapat disamakan dengan penggantian kerugian (indemnity) pada praktek asuransi saat ini, sebagai suatu bentuk perlindungan keuangan bagi akhli waris dari sebuah kematian yang tidak diharapkan oleh korban. ${ }^{3}$

Perkembangan asuransi syariah sebagaimana tersebut diatas di satu sisi menunjukkan keberadaan asuransi syariah di Indonesia dapat diterima oleh masyarakat Indonesia, yang mayoritas menganut agama Islam. Hal ini sesuai dengan tujuan dari didirikan asuransi syariah di Indonesia, yaitu untuk memberikan perlindungan rasa aman atas diri seseorang maupun harta bendanya, melalui suatu perjanjian yang dilandasi pada syariat Islam, akan tetapi

\footnotetext{
${ }^{1}$ Sri Rejeki Hartono.(2001). Hukum Asuransi dan Perusahaan Asuransi, Jakarta: Sinar Grafika, hlm 69 ${ }^{2}$ Ibid., hlm 32 .

${ }^{3}$ AM. Hasan Ali, (2004).Asuransi Dalam Perspektif Hukum Islam, Jakarta: Pranada Media, hlm. 68.
} 
di sisi lain ditinjau dari dasar hukum yang mengatur asuransi syariah secara konstitusional keberadaan asuransi syariah di Indonesia masih lemah dan masih membutuhkan adanya political will (kebijakan politik) yang mendukung dari pemerintah Indonesia.

Demikian juga halnya dengan salah satu Badan Usaha Milik Daerah yang bergerak dalam bidang asuransi yaitu PT. Jamkrida NTB Bersaing yang ditetapkan melalui Peraturan Daerah Provinsi Nusa Tenggara Barat Nomor 2 Tahun 2012. Perseroan Terbatas Penjaminan Kredit Daerah Nusa Tenggara Barat Bersaing sudah menjamin kredit sebanyak 30 ribu pelaku usaha mikro kecil dan menengah (UMKM) sejak perusahaan daerah tersebut mulai beroperasi pada 2013.

Pangsa pasar penjaminan kredit yang dijamin oleh PT. Jamkrida NTB Bersaing masih relatif kecil karena penjaminan hanya pada kredit yang disalurkan oleh PT Bank NTB dan PT Bank Perkreditan Rakyat (BPR) NTB dengan pangsa pasar sebesar 10-15 persen dari seluruh pangsar kredit perbankan di NTB.

Akan tetapi dengan peralihan Bank NTB menjadi Bank syariah, maka beriplikasi terhadap nasabah Jamkrida, karena sebagian besar nasabah PT. Jamkrida adalah nasabah Bank NTB. Oleh karena itu pilihan pengembangan investasi PT. Jamkrida NTB Bersaing melalui pembentukan Unit Syariah menjadi sangat urgen untuk menyesuaikan dengan terjadinya konversi Bank NTB yang awalnya menerapkan prinsip konvensional menjadi prinsip syariah. Bagaimana pengaturan pembukaan Unit syariah pada Badan Usaha Milik Daerah PT. Jamkrida NTB Syariah, dan apakah pengembangan investasi melalui pembukaan unit syariah dapat menjadi satu kesatuan dengan Lembaga Penjaminan Kredit atau harus merupakan kelembagaan tersendiri.

\section{B. METODE PENELITIAN}

Penelitian ini adalah penelitian hukum normatif (legal research), dengan menggunakan pendekatan konseptual (conceptual approach), pendekatan perundang-undangan (statute approach), pendekatan kasus (casse approach). ${ }^{4}$

\section{PEMBAHASAN}

\section{Pendirian Unit Syariah pada Lembaga Penjaminan Kredit Daerah NTB Bersaing}

PT. Jamkrida NTB Bersaing adalah satu perusahaan/lembaga penjaminan yang dimiliki oleh Pemerintah Provinsi NTB.Tujuan pendirian perusahaan ini adalah untuk mendukung program Pemerintah NTB dalam mengembangkan UMKM dan Koperasi di NTB.

Jumlah UMKM di NTB lebih dari 624.000 unit usaha.Jumlah itu belum termasuk koperasi yang juga cukup banyak.Dari 624.000 UMKM di NTB hanya sedikit sekali yang dapat mengakses pinjaman/kredit/pembiayaan dari perbankan maupun lembaga keuangan lainnya

Salah satu sebab sulitnya UMKM maupun koperasi dalam mengakses kredit/pinjaman dari lembaga perbankan/lembaga keuangan lainnya adalah karena UMKM dan koperasi tidak memiliki agunan atau agunannya tidak cuku[p untuk memenuhi persyaratan kredit/pinjaman yang ditetapkan oleh Bank/Lembaga Keuangan. Karena itu dibutuhkan lembaga penjaminan agar persyaratan bankable tersebut dapat dipenuhi.Lembaga penjamin ini berfungsi sebagai "pengganti" agunan/collateral; baik yang tidak ada maupun yang kurang.

Berkaitan dengan fungsinya sebagai "pengganti" agunan/collateral, maka PT. Jamkrida NTB Bersaing harus mampu memberikan penjaminan (menggantikan agunan) UNTUK +/- 624.000

${ }^{4}$ Johnny Ibrahim.(2008).Teori \& Metodologi Penelitian Hukum Normatif, Malang: Buyumedia Publishing, hlm 310-320. 
UMKM di NTB.Jumlah ini belum termasuk koperasi yang juga jumlahnya sangat banyak. Koperasi menjadi salah satu kegiatan usaha yang dapat dijamin oleh lembaga penjaminan.

Bahwa modal sendiri perusahaan (kemampuan perusahaan untuk menjamin) harus "sepadan" dengan jumlah kredit/pinjaman UMKM yang akan dijamin oleh PT. Jamkrida NTB Bersaing; baik yang melalui PT. Bank NTB Syariah, PD. BPR NTB maupun dengan perbankan/lembaga lainnya.

Oleh karena itu maka Otoritas Jasa Keuangan (OJK) sebagai regulator yang mengatur dan mengawasi operasional lembaga penjaminan sudah menetapkan bahwa kepemilikan modal lembaga penjaminan harus mencapai minimal RP. $50 \mathrm{M}$ apabila sudah beroperasi selama 5 (lima) tahun.

Ketentuan mengenai batas minimal kepemilikan modal sendiri ini tertuang pada pasal 31 ayat (2) Peraturan OJK Nomor: 2/OJK.05/2017 tentang Penyelenggaraan Usaha Lembaga Penjaminan

Mengingat izin operasional PT. Jamkrida NTB Bersaing diperoleh sejak tanggal 6 Desember 2012, maka operasional PT. Jamkrida NTB Bersaing sudah melebihi 5 (lima) tahun dan karena itu, maka pemenuhan modal tersebut menjadi sebuah kewajiban bagi pemilik saham.

Saat ini jumlah modal sendiri yang dimiliki oleh PT. Jamkrida NTB Bersaing adalah sebesar Rp. 32,50 M. modal ini berasal dari Pemerintah Provinsi NTB sebesar Rp. 27 M; Pemerintah Kota Mataram sebesar Rp 1 M; Pemerintah Kabupaten Lombok Barat sebesar Rp. 1 M; Pemerintah kabupaten Lombok Tengah sebesar Rp. 1 M; Pemerintah Kabupaten Bima sebesar Rp. 1,5 M dan Pemerintah Kota Bima sebesar Rp. 1 M.

Upaya untuk mendapatkan tambahan modal dari Pemerintah Kabupaten/Kota se NTB tidak dapat diharapkan akan terpenuhi, mengingat kondisi APBD II masing-masing Kabupaten/Kota se NTB yang relative terbatas.

Dengan demikian masih terdapat kekurangan modal sendiri sebesar Rp. 17,50 M. Pemenuhan Modal sebesar Rp. 17,50 M ini sangat diharapkan berasal dari Pemerintah Provinsi NTB sebagai Pemilik saham Pengendali.

Penambahan/peningkatan modal sendiri ini; selain untuk memperbesarkapasitas penjaminan (disesuaikan dengan jumlah penjaminan) juga diharapkan akan berdampak promosi bagi PT. Jamkrida NTB Bersaing terutama pada perbankan/lembaga keuangan lainnya. Modal yang besar akan dapat meningkatkan kepercayaan Bank/Lembaga keuangan dalam bekerja sama dengan PT. Jamkrida NTB Bersaing.

Harapan berikutnya adalah dengan meningkatnya kepercayaan tersebut akan meningkatkan volume penjaminan yang berakibat pada peningkatan pendapatan/perolehan Imbal Jasa Penjaminan dan kemudian diharapkan dapat berimplikasi pada peningkatan laba perusahaan dan setoran devident kepada pemilik saham.

Selain itu; sebagai perusahaan milik Pemerintah Provinsi NTB, maka PT. Jamkrida NTB Bersaing harus bekerjasama dengan PT. Bank Syariah maupun PD. BPR NTB dalam memberikan penjaminan kredit kepada UMKM maupun koperasi. Karena itu, maka sistem penjaminan pada PT. Jamkrida NTB Bersaing harus "selaras" dengan PT. Bank Syariah. Artinya PT. Jamkrida NTB Bersaing harus menjalankan sistem penjaminan berbasis Syariah.

Karena itu, maka pendirian unit usaha syariah pada PT. Jamkrida NTB Bersaing menjadi hal sangat mendesak; sebab apabila PT. Jamkrida NTB Bersaing tidak memiliki/menjalankan usaha syariah maka akan dipastikan tidak akan mendapatkan kesempatan untuk memberikan penjaminan kredit pada PT. Bank NTB Syariah.

Berdasarkan hal tersebut, maka PT. Jamkrida NTB Bersaing berencana untuk menjalankan bidang usaha berdasarkan prinsip Syariah dengan membuka "Unit Usaha Syariah". 
Berdasarkan Peraturan Otoritas Jasa Keuangan (POJK) Nomor: 2/POJK.05/2017, tentang Penyelenggaraan Usaha Lembaga Penjaminan menyebutkan bahwa lembaga penjaminan selain dapat menjalankan usaha dengan sistem konvensional juga dapat menjalankan usaha dengan sistem Syariah.

Untuk dapat menjalankan bisnis tersebut diperlukan adanya "modal kerja khusus" sebesar $10 \mathrm{M}$ (sepuluh miliar rupiah). Modal ini adalah salah satu syarat untuk mendapatkan izin menjalankan bisnis penjaminan kredit dengan sistem Syariah sebagaimana tertuang dalam Peraturan Peraturan Otoritas Jasa Keuangan (POJK) Nomor: 2/POJK.05/2017, tentang penyelenggaraan Usaha Lembaga Penjaminan.

Untuk mewujudkan hal tersebut, maka penambahan penyertaan modal dari Pemerintah Provinsi NTB sangat diharapkan.

\section{b. Kelengkapan Pendirian Unit Syariah}

Dalam mendirikan perusahaan penjaminan pembiayaan syariah diperlukan beberapa syarat yang harus dipenuhi. Proses pendirian perusahaan penjaminan pembiayaan syariah jika dilakukan oleh perusahaan BUMN yang akan mendirikan Perusahaan Anak harus memenuhi ketentuan pada Bapepam-LK Depeku, Dewan Syariah Nasional dan Notaris.

Adapun syarat yang harus dipenuhi dalam pendirian unit syariah:

1. Akta pendirian Perusahaan Penjaminan termasuk anggaran dasar yang telah disahkan oleh instansi berwenang.

2. Daftar susunan Direksi / Pengurus dan Dewan Komisaris/ Pengawas, disertai dengan :

a. Pasfoto 1 ( satu ) bulan terakhir ukuran $4 \times 6 \mathrm{~cm}$;

b. Fotokopi identitas diri berupa Kartu Tanda Penduduk ( KTP ) atau paspor;

c. Daftar riwayat hidup;

d. surat pernyataan :

i. tidak tercatat dalam daftar kredit macet di sektor perbankan;

ii. tidak pernah dihukum karena tindak pidana kejahatan;

iii. tidak pernah dinyatakan pailit atau dinyatakan bersalah yang mengakibatkan suatu perseroan/perusahaan dinyatakan pailit berdasarkan keputusan pengadilan yang mempunyai kekuatan hukum tetap;

iv. tidak merangkap jabatan pada penjamin dan/atau penjamin ulang lain kecuali jabatan sebagai komisaris/dewan pengawas/badan pengawas Penjamin Ulang bagi Direksi/Pengurus;

v. Tidak merangkap jabatan lebih dari 3 ( tiga ) Penjamin dan/ atau Penjamin Ulang, dan/atau badan usaha lain bagi komisaris/dewan pengawas/badan pengawas;

e. surat keterangan atau bukti tertulis berpengalaman di bidang penjaminan atau perbankan atau lembaga keuangan lainnya selama 2 ( dua ) tahun bagi salah satu direksi atau pengurus;

3. Data pemegang saham atau anggota dalam hal :

a. perorangan, wajib dilampiri dengan dokumen sebagaimana dimaksud dalam angka 2 huruf a, b dan huruf c serta surat pernyataan bahwa setoran modal tidak berasal dari pinjaman dan kegiatan pencucian uang ( money laundring );

b. Badan hukum, wajib dilampiri dengan :

i. Akta pendirian badan hukum, termasuk anggaran dasar berikut perubahan perubahan yang telah mendapat pengesahan dari instansi berwenang;

ii. Laporan keuangan yang telah diaudit oleh akuntan publik dan/atau laporan keuangan terakhir; 
iii. Dokumen sebagaimana dimaksud dalam angka 2 huruf a,b dan huruf c bagi pemegang saham dan direksi atau pengurus;

4. Struktur organisasi yang memiliki fungsi pengelolaan risiko, fungsi pengelolaan keuangan, fungsi pelayanan dan pengembangan informasi/database terjamin.

5. Sistem dan prosedur kerja Penjamin

6. Rencana Kerja ( business plan ) untuk 3 ( tiga ) tahun pertama yang sekurang-kurangnya memuat :

a. Studi kelayakan mengenai peluang pasar dan potensi ekonomi;

b. Rencana kegiatan usaha calon Perusahaan Penjaminan Pembiayaan Syariah dan langkah - langkah kegiatan yang akan dilakukan dalam mewujudkan rencana dimaksud, dan;

c. Proyeksi neraca, laporan laba rugi dan laporan arus kas bulanan selama 12 (dua belas ) bulan yang dimulai sejak Penjamin melakukan kegiatan operasional;

7. Daftar sumber daya manusia yang memiliki pengalaman di bidang penjaminan.

8. Fotocopy bukti pelunasan modal setor minimal dalam bentuk deposito Berjangka atas nama Penjamin pada salah satu Bank Umum di Indonesia Dan dilegalisasi oleh bank menerima setoran yang masih berlaku selama dalam proses pengajuan izin usaha;

9. Bukti kesiapan operasional antara lain berupa : a Daftar aktiva tetap dan inventaris; b Bukti kepemilikan, penguasaan atau perjanjian sewa menyewa gedung kantor; c Contoh formulir, termasuk Sertifikat Penjaminan yang akan digunakan untuk operasional Penjamin; d Nomor Pokok Wajib Pajak (NPWP);

10. Rekomendasi DSN dan daftar Dewan Pengawas Syariah yang direkomendasikan DSN

\section{Pengembangan Investasi Lembaga Penjaminan Kredit Konvensional melalui Pembu- kaan Unit Syariah}

Terkait dengan pembukaan unit syariah pada PT. Jamkrida NTB Bersaing berdasarkan Undang-undang Nomor 1 Tahun 2016 Tentang Lembaga Penjaminan dan Penjaminan ulang antara lain ditentutan :

1. Wajib terlebih dahulu mendapat izin usaha dari Otoritas Jasa Keuangan.

Untuk mendapatkan izin usaha sebagaimana dimaksud pada ayat (1) harus dipenuhi persyaratan:

a. akta pendirian badan hukum;

b. anggaran dasar;

c. susunan organisasi;

d. data direksi/pengurus dan data komisaris/dewan pengawas/pengawas;

e. data pemegang saham atau anggota;

f. sistem dan prosedur kerja usaha Penjaminan dan Penjaminan Ulang;

g. keterangan mengenai tenaga ahli penjaminan;

h. modal disetor;

i. kelayakan rencana kerja;

j. kesiapan infrastruktur;

k. konfirmasi dari otoritas pengawas di negara asal pihak asing, jika terdapat penyertaan langsung pihak asing; dan

1. syarat lain yang diperlukan untuk mendukung pertumbuhan usaha yang sehat.

2. Perusahaan Penjaminan dapat melakukan sebagian kegiatan usaha Penjaminan berdasarkan PrinsipSyariahdenganmembentukUUS, denganketentuanbahwadalamanggarandasarnya, wajib memuat maksud dan tujuan perusahaan untuk menjalankan sebagian kegiatan usaha Penjaminan Berdasarkan Prinsip Syariah. 
3. Permodalam;

Berdasarkan Peraturan Menteri Keuangan No. 222 /PMK.010/2008 tentang Perusahaan Penjamin Kredit dan Perusahaan Penjamin Ulang Kredit ditentukan bahwa :

a. Rp. 100 miliar, untuk lingkup Nasional;

b. Rp. 50 miliar, untuk ingkup Provinsi

Jika mengacu pada Peraturan Daerah Nomor 2 Tahun 2012 Tentang PT. Jamkrida NTB Bersaing bahwa maksud dan Tujuan Pembentukan Perseroan adalah :

a. untuk melakukan penjaminan kredit bagi KUMKM; dan

b. untuk pedoman bagi para pemegang saham dalam hal bertindak untuk dan atas nama perseroan.

Dengan tujuan untuk;

a. Menciptakan kesempatan pada usaha mikro di bidang perdagangan, industry pertanian, perternakan,perkebunan, untuk dapat mengakses permodalan pada perbankkan melalui lembaga penjaminan;

b. Menciptakan kemandirian Ekonomi Daerah dengan menggali potensi KUKM;

c. Memperluas kesempatan kerja di Daerah;

d. Meningkatkan peran KUKM dalam menggali Pendapat Asli Daerah ; dan

e. Meningkatkan kesejahteraan rakyat.

Untuk mewujudkan maksud dan tujuan tersebut diatas Pemerintah Daerah Propinsi Nusa

Tenggara Barat telah menetapkan :

1. Jumlah Modal Dasar perseroan paling sedikit sebesar RP.75 .000.000.000 (tujuh puluh lima miliyar rupiah). Jumlah Modal Disetor sedikit sebesar Rp. 25.000.000.000 (dua puluh lima milyar rupiah)

2. Modal persoalan terdiri atas saham-saham

3. Pemegangan saham perseroan terdiri dari.pemerintah provinsi dan pemerintahkabupaten / kota se Provinsi Nusa Tenggara Barat.

4. Paling sedikit 51\%(lima puluh satu persen)dari seluruh saham harus dimiliki oleh pemerintah Daerah.

Terkait dengan prinsip pengelolaan Perseroan dalam Pasal 28 Peraturan Daerah Nomor : 2 Tahun 2012 telah menentukan yaitu :

a. Pengelolaan Perseroan harus dilakukan secara professional dengan mengikuti prinsip-prinsip lembaga usaha ekonomi yang berorientasi keuntungan (profit oriented)

b. Untuk melaksanakan prinsip-prinsip pengelolaan sebagaimana dimaksud pada ayat (1) Dewan Komisaris dan Direksi Perseroan diserahkan kepada pihak yang memiliki syarat kompetensi, professional, dan memiliki integritas moral yang dapat dipertanggung jawabkan.

Sedangkan bidang usaha yang merupakan ruang lingkup kegiatan usaha PT. Jamkrida NTB Bersaing melalui Pasal 29 disebutkan :

a. Untuk mencapai maksud dan tujuan sebagaimana dimaksud dalam pasal 5 perseroan melaksanakan bidang usaha pemberian jasa penjaminan kredit pembiayaan dalam bentuk penyediaandanapertanggunganresikobagiKUKMyangtidakdapatmemmenuhikewajibannya dalam menyediakan agunan .

b. Rincian bidang usaha sebagaimana dimaksud pada ayat(1) dituangkan dalam Angaran Dasar Peseroan beserta perubahannya, guna meyesuaikan dengan perubahan lingkungan usaha dan perkembangan perseroan.

c. Dalam rangka peningkatan dan pengembangan unit usaha.yang potensial dan kegiatan usaha spesifik tertentu yang terkait dengan bidang usaha komersial disetujui dalam RUPS sesuai dengan ketentuan peraturan perundang-undangan. 
Dengan mengacu pada ketentuan-ketentuan diatas menunjukkan bahwa PT. Jamkrida NTB Bersaing tidak secara khusus menyebutkan bahwa kegiatan perseroan dijalankan berdasarkan prinsip konvensional. Meskipun secara terminology istilah "kredit" berkonotasi sebagai kegiatan konvensional yang berorientasi pada "bunga". Sedangkan prinsip syariah menggunakan istilah "pembiayaan" yang berorientasi pada "bagi hasil". Oleh karena itu secara yuridis pembukaan unit syariah pada PT. Jamkrida NTB Bersaing disamping wajib memenuhi aspek permodalan yaitu minimal Rp. 10.000.000.000 (sepuluh milyar rupiah), juga wajib melakukan perubahan terhadap anggaran dasar dan anggaran rumah Perseroan dengan mencantumkan prinsip syariah sebagai salah satu unit usaha Perseroan, sebab secara operasional dua prinsip ini selain memiliki beberpa persamaan, namun juga ada beberapa hal yang secara prinsip berbeda.

Asuransi takaful umum merupakan bagian dari asuransi syariah, sehingga untuk menemukan unsur-unsur asuransi takaful umum, dapat dilihat dari pengertian asuransi syariah.

Ketentuan Umum Fatwa DSN-MUI No: 21/DSN-MUI/X/2001, tentang Pedoman Umum Asuransi Syariah, dalam poin (1), memuat pengertian asuransi syariah, sebagai berikut;

"Asuransi syariah (ta'amin, Takaful atau Tadhamin) adalah usaha saling melindungi dan tolong menolong di antara sejumlah orang / pihak, melalui investasi dalam bentuk aset dan / atau tabarru' yang memberikan pola pengembalian untuk menghadapi risiko tertentu melalui akad (perikatan) yang sesuai dengan syariah".

Pengertian asuransi syariah di atas, menunjukkan tujuan dan beberapa unsur asuransi syariah umumnya, termasuk asuransi takaful umum. Tujuan asuransi takaful umum adalah untuk memberikan perlindungan keamanan atas harta benda seseorang, dengan cara saling tolong menolong dan saling menanggung risiko di antara sesama peserta, dalam mengatasi risiko yang mengancam obyek asuransi.

Berdasarkan ketentuan tersebut di atas, pada umumnya perusahaan asuransi di Indonesia berbentuk PT. Mengingat landasan operasional asuransi syariah di Indonesia, adalah peraturan perundangan asuransi konvensional, maka bentuk perusahaan asuransi syariah adalah PT, termasuk asuransi takaful umum berbentuk PT.

Ketentuan pemberlakuan peraturan perundangan asuransi konvensional pada asuransi syariah, dapat dilihat pada beberapa peraturan perundangan antara lain, dalam surat keputusan Menteri Keuangan Republik Indonesia, Nomor 246/kmk.06/2003, tentang Perizinan Usaha Kelembagaan Perusahaan Asuransi dan Perusahaan Reasuransi, dalam Pasal 4 ayat (1), menentukan;

"Untuk pendirian perusahaan asuransi atau perusahaan reasuransi dengan prinsip syariah, harus memenuhi persyaratan dalam Pasal 2 Surat Keputusan Menteri Keuangan No.246/kmk.06/2003, yaitu persyaratan dan tata cara memperoleh izin usaha perusahaan asuransi dan perusahaan reasuransi umum (konvensional)".

Jafril Khalil mengemukakan, berkaitan dengan Fatwa DSN-MUI, terdapat beberapa jenis akad yang digunakan dalam asuransi syariah, yaitu; ${ }^{5}$

a. Akad tabarru' yang diatur dalam Fatwa DSN-MUI No. 53/DSN-MUI/III/2006 yaitu semua bentuk akad yang dilakukan dengan tujuan kebajikan dan tolong menolong, bukan sematamata untuk tujuan komersial. Di dalam akad tabarru' menggunakan akad hibah, maksudnya peserta memberikan hibah yang akan digunakan untuk menolong peserta lain yang terkena risiko atau musibah, sementara perusahaan asuransi sebagai pengelola dana hibah.

b. Akad tijarah adalah semua bentuk akad yang dilakukan untuk tujuan komersial. Akad tijarah dalam asuransi syariah menggunakan akad mudharabah, yaitu akad yang diadakan paling

${ }^{5}$ Jafril Khalil dalam Abdullah Amrin, Op Cit, hlm 33-34.

Pengembangan Investasi Melalui Pendirian Unit Syariah... | Sulistianingsih Rahayu 95 
sedikit antara dua pihak, yaitu pihak pemilik modal (shahib al-mal) mempercayakan sejumlah dana kepada pihak lain atau pengusaha (mudharib), untuk menjalankan suatu aktivitas atau usaha, yang didasari pada saling bagi hasil di antara para pihak.

Salah satu bentuk akad mudharabah adalah mudharabah musytarakah, yang dapat digunakan dalam asuransi takaful umum. Akad mudharabah musytarakah diatur dalam Fatwa DSN-MUI No: 50/DSN-MUI/III/2006, memberikan defenisi sebagai berikut;

"Mudharabah musytarakah adalah bentuk akad mudharabah, di mana pengelola (mudharib) menyerahkan modalnya dalam kerja sama investasi tersebut".

Akad mudhabarah musytarakah merupakan pengembangan dari akad mudharabah. Letak perbedaan antara mudharabah dengan mudharabah musytarakah pada kesertaan modal. Di dalam mudharabah musytarakah, mudharib (pengusaha) selain berfungsi sebagai pengelola, juga berfungsi sebagai sahibul mal kedua, karena turut berkontribusi dalam kesertaan modal.

Praktek mudharabah musytarakah dalam asuransi takaful umum, adalah peserta sebagai sahibul mal, membayar kontribusi dan premi tersebut diinvestasikan ke dalam investasiinvestasi syariah, sedangkan perusahaan asuransi takaful umum bertindak sebagai mudharib. Pada saat yang bersamaan perusahaan asuransi takaful umum, menyertakan juga dananya untuk diinvestasikan secara bersamaan dengan dana kontribusi peserta, pada proyek investasi tertentu. Apabila proyek investasi mendapat keuntungan, pertama-tama dibagi nisbah keuntungan antara peserta dengan perusahaan asuransi takaful umum.

Akad wakalah bil-ujrah diatur dalam Fatwa DSN-MUI No: 52/DSN-MUI/III/2006, yang mempunyai makna sebagai pelimpahan, pendelegasian wewenang atau kuasa dari pihak pertama kepada pihak kedua untuk melaksanakan sesuatu atas nama pihak pertama dan untuk kepentingan dan tanggungjawab sepenuhnya oleh pihak pertama.

Wakalah bil ujrah dalam akad asuransi syariah adalah akad pemberian kuasa dari peserta kepada perusahaan asuransi syariah sebagai pengelola, untuk mengelola dana peserta dan atau melakukan kegiatan lain dengan imbalan pemberian ujrah (fee)

Akad al-Qardh diatur dalam Fatwa DSN-MUI No; 19/DSN-MUI/IV/2001, adalah pinjaman yang diberikan pada nasabah yang memerlukan secara sukarela, dan nasabah wajib mengembalikan jumlah pokok pada waktu yang telah disepakati bersama.

Al-Qardh dalam asuransi takaful umum merupakan akad pinjaman murni dari dana milik perusahaan asuransi takaful umum sebagai pengelola, untuk dana tabarru', apabila dalam keadaan dana tabarru' tidak mencukupi untuk membayar klaim yang terjadi, dengan ketentuan pengembalian atas pinjaman tersebut dilakukan hanya atas pokok pinjaman ditambah biaya administrasi yang wajar (jika ada) setelah dana tabarru' memiliki surplus pada periode-periode berikutnya.

Kemudian terkait dengan pengajuan penggantian kerugian atau klaim asuransi dalam asuransi takaful umum, adalah merupakan pengajuan hak peserta kepada perusahaan asuransi takaful umum sebagai pengelola, untuk meminta penggantian kerugian, atas terjadi risiko atau peristiwa tidak pasti yang menimpa obyek asuransi.

Pada dasarnya semua perusahaan asuransi syariah, termasuk perusahaan asuransi takaful umum, dalam menghadapi pengajuan klaim dari peserta, perusahaan asuransi takaful umum selaku pengelola, harus memenuhi kewajibannya untuk membayar penggantian kerugian dengan cepat, sesuai dengan ketentuan yang telah diperjanjikan dan yang telah dicantumkan dalam polis asuransi.

Perusahaan asuransi takaful umum sebagai pengelola, dalam pemenuhan kewajibannya untuk membayar penggantian kerugian, sesungguhnya tidak ada alasan untuk memperlambat pelaksanaan penggantian kerugian, karena dana untuk pemenuhan penggantian kerugian 
sudah tersedia, yaitu dana tabarru' yang sudah dari awal sudah dipersiapkan untuk membayar penggantian kerugian bagi peserta yang dikenai musibah atau risiko.

Di dalam proses pengajuan klaim dan penggantian kerugian pada asuransi syariah termasuk asuransi takaful umum, harus memperhatikan beberapa hal penting, yaitu; ${ }^{6}$

a. Jenis kerugian yang diasuransikan

Secara umum jenis kerugian dalam asuransi syariah termasuk asuransi takaful umum terdiri dari;

1. Kerugian seluruhnya (total loss)

2. Kerugian sebagian (partial loss)

3. Kerugian pihak ketiga.

Kerugian seluruhnya (total loss) adalah kerugian yang diderita peserta, akibat dari kerusakan seluruh obyek asuransi atau kerusakan yang mencapai 75\% dari obyek asuransi, misalnya rumah yang merupakan obyek asuransi terbakar habis atau mobil yang merupakan obyek asuransi dinyatakan hilang, atau baik rumah maupun mobil mengalami kerusakan $75 \%$, sehingga tidak dapat dimanfaatkan lagi. Besar penggantian kerugian untuk kerugian seluruhnya (total loss), sejumlah nilai pertanggungan atau jumlah pertanggungan yang telah disepakati dalam polis asuransi.

Kerugian sebagian (partial loss) adalah kerugian yang diderita peserta akibat dari kerusakan obyek asuransi tidak seluruhnya atau tidak termasuk katagori kerusakan seluruhnya (total loss). Jumlah penggantian kerugian untuk kerugian sebagian (partial loss) adalah sejumlah kerugian yang diderita sesungguhnya, yang didasari pada penilaian kerugian oleh lembaga independen, sesuai dengan jenis asuransi takaful umum yang diadakan.

Kerugian pihak ketiga adalah kerugian yang diderita oleh pihak ketiga akibat dari tindakan yang dilakukan oleh peserta. Jumlah penggantian kerugian untuk pihak ketiga adalah sejumlah kerugian yang diderita pihak ketiga sesungguhnya, sampai batas jumlah yang diperjanjikan dan yang dicantumkan dalam polis asuransi.

Di dalam praktek asuransi takaful umum, jumlah pertanggungan yang sekaligus berfungsi sebagai dasar untuk menentukan jumlah atau besar penggantian kerugian, tercantum dalam Ikhtisar Manfaat Takaful.

Selanjutnya terkait dengan klain asuransi kerugian, peserta yang mengalami musibah atau risiko yang menimpa obyek asuransi, harus segera melaporkan peristiwa tersebut secara lisan yang diikuti tertulis kepada perusahaan asuransi takaful umum, selanjutnya peserta menunjukkan fakta-fakta yang utuh, dan menyerahkan bukti-bukti kerugian serta dokumendokumen, sebagaimana yang disyaratkan secara standar dalam industri asuransi Indonesia. Setelah laporan dan dokumen pendukung diterima pengelola asuransi takaful umum, kemudian pengelola mengadakan analisis administrasi, dan diteruskan pada pemeriksaan lapangan terhadap obyek asuransi, untuk menentukan penyebab kerugian dan jumlah kerugian yang diderita peserta, dan apabila klaim asuransi ditolak, pengelola harus dengan cepat menyampaikan surat penolakan klaim yang diajukan peserta, dan apabila klaim asuransi diterima, pengelola menghubungi peserta untuk mengadakan kesepakatan tentang bentuk dan jumlah penggantian kerugian, dan setelah kesepakatan terjadi, sesuai dengan peraturan perundangan yang berlaku maka pembayaran penggantian kerugian segera dilaksanakan, dan tidak boleh melebihi 30 (tiga puluh) hari sejak terjadinya kesepakatan antara peserta dengan perusahaan asuransi takaful umum tentang bentuk dan jumlah penggantian kerugian.

\footnotetext{
${ }^{6}$ Muhammad Syakir Sula, Op Cit, hlm 260-263.
} 


\section{KESIMPULAN}

Bahwa pendirian lembaga penjaminan kredit secara yuridis normative diatur dalam UndangUndang Republik Indonesia Nomor 1 tahun 2016 tentang Penjaminan, Peraturan Menteri Keuangan Nomor 222/PMK.010/2008 tentang Perusahaan Penjaminan Kredit dan Perusahaan Penjaminan Ulang Kredit dan Peraturan Otoritas Jasa Keuangan Nomor 2/POJK 05/2017 tentang Penyelenggara Usaha Lembaga Penjamin. Bagi Perusahaan yang telah memperoleh izin usaha pendirian lembaga penjamin kredit (prinsip konvensional) dapat membuka unit penjaminan syariah dengan terlebih dahulu mendapat izin usaha dari Lembaga Otoritas Jasa Keuangan. Bahwa berdasarkan ketentuan Pasal 11 Peraturan Menteri Keuangan Nomor 222/ PMK.010/2008 tentang Perusahaan Penjaminan Kredit dan Perusahaan Penjaminan Ulang Kredit : Jumlah modal disetor atau simpanan pokok, simpanan wajib dan hibah penjamin ditetapka paling sedikit Rp. 100.000.000.000 (seratus miliar untuk lingkup nasional dan Rp. 50.000.000.000 (lima puluh miliar) untuk lingkup propinsi. Kemudian untuk Penjamin dan Penjamin Ulang yang membuka Unit Usaha Syariah wajib menyediakan dana awal paling sedikit sebesar Rp10.000.000.000,00 (sepuluh miliar rupiah) serta membuka Kantor Cabang Syariah yang baru atau mengubah kegiatan usaha Kantor Cabang yang melakukan kegiatan usaha secara konvensional menjadi Kantor Cabang Syariah.

\section{Daftar Pustaka}

\section{Buku-buku}

Abdullah Amrin.(2006). Asuransi Syari'ah, Keberadaan dan Kelebihannya Di Tengah Asuransi Konvensional, Jakarta : Gramedia

AM. Hasan Ali.(2004). Asuransi Dalam Perspektif Hukum Islam, Jakarta: Pranada Media.

Departemen Pendidikan Nasional.(2003). Kamus Besar Bahasa Indonesia, Balai Pustaka.

Fathhurrahman Djamil.(2001).Hukum Perjanjian Syariah, dalam Kompilasi Hukum Perikatan oleh Mariam Darus Badrulzaman, Bandung: Citra Aditya Bakti.

Johnny Ibrahim.(2008). Teori \& Metodologi Penelitian Hukum Normatif, Malang: Buyumedia Publishing.

Sri Rejeki Hartono.(2001). Hukum Asuransi dan Perusahaan Asuransi, Jakarta: Sinar Grafika. Al-Qur'an, Ensiklopedi, Kamus

Al-Qur'an dan Terjemahannya, Departemen Agama Republik Indonesia, PT Syaamil Cipta Madia.

\section{Perundang-Undangan}

Undang-Undang Nomor 40 Tahun 1997 tentang Perseroan Terbatas

Undang-Undang Nomor 25 Tahun 1992 tentang Perkoperasian

Keputusan Menteri Keuangan Nomor 424/kmk.06/2006 tentang Kesehatan keuangan Perusahaan Asuransi dan perusahaan Reasuransi

Keputusan Menteri Keuangan Nomor 426/kmk.06/2003 tentang Perizinan dan Kelembgaan Perusahaan Asuransi dan Perusahaan Reasuransi

Keputusan Direktur Jendral Lembaga Keuangan Nomor 4499/lk/2000 tentang Jenis Penilaian dan pembatasan Investasi Perusahaan Asuransi dan Reasuransi dengan Sistem Syariah 
Fatwa Dewan Syar'ah Nasional Nomor 21/DSN-MUI/X/2001 tentang Pedoman Umum Asuransi Syar'ah

Fatwa Dewan Syari'ah Nasional Nomor 51/DSN-MUI/III/2006 tentang Akad Mudharabah Musytarakah Pada Asuransi Syari'ah

Fatwa Dewan Syari'ah Nasional Nomor 52/DSN-MUI/III/2006 tentang Akad Wakalah Bil Ujrah Pada Asuransi Syari'ah

Fatwa Dewan Syari'ah Nasional Nomor 53/DSN-MUI/III/2006 tentang Akad Tabarru' Pada Asuransi Syari'ah Dan Reasuransi Syari'ah 